\title{
Between Scylla and Charybdis: A Literature Review of Sexual Abuse Allegations in Divorce Proceedings
}

\author{
Anne E. Smit*, Masha V. Antokolskaia, Catrien C. J. H. Bijleveld \\ Vrije Universiteit, Amsterdam, The Netherlands \\ Email: ${ }^{*}$ a.e.smit@vu.nl
}

Received 8 June 2015; accepted 21 August 2015; published 25 August 2015

Copyright (C) 2015 by authors and Scientific Research Publishing Inc.

This work is licensed under the Creative Commons Attribution International License (CC BY). http://creativecommons.org/licenses/by/4.0/

(c) (i) Open Access

\begin{abstract}
In this study international literature is reviewed on allegations of child sexual abuse (CSA) during divorce proceedings. It aims to build upon the existing knowledge on this topic by combining empirical findings from various disciplines. We attempted to answer four research questions that focus on 1) the prevalence of CSA allegations in divorce procedures; 2) the response of family court judges; 3 ) the ratio of founded vs. unfounded allegations of CSA under these circumstances; and 4) the possible consequences of the false positives and false negatives in legal decision making for the children and parents involved. The literature study shows that civil judges often seek professional help. The judge generally tends to (temporarily) stop contact between accused parent and child during an investigation. Additionally, there is a general concern about the many actors involved in such cases. It can also be cautiously assumed that one in seven to eight allegations is not founded. We conclude that civil judges have to make important decisions under difficult circumstances: there is little or no evidence, no guidelines, external help lengthens the trial, and there are serious consequences of false positives and false negatives in legal decision-making. Literature is surprisingly scarce and generally outdated.
\end{abstract}

\section{Keywords}

Sexual Abuse, Accusation, Marriage, Divorce, Custody and Access, Family Court

\section{Introduction}

In the Netherlands in 2009 a divorced father of four children was released after seven months in remand. During

\footnotetext{
${ }^{*}$ Corresponding author.
}

How to cite this paper: Smit, A. E., Antokolskaia, M. V., \& Bijleveld, C. C. J. H. (2015). Between Scylla and Charybdis: A Literature Review of Sexual Abuse Allegations in Divorce Proceedings. Psychology, 6, 1373-1384.

http://dx.doi.org/10.4236/psych.2015.611134 
their parents' divorce proceedings the children had accused their father of sexually abusing them. The case had been sent to the Dutch National Expert Group Sexual Offences, whose conclusion was that the accusations made by the children were unfounded, and therefore that the father had been falsely accused. He was acquitted from the alleged sexual abuse of three of his children. Despite these findings the mother remained convinced that the abuse had in fact taken place, and persisted in accusing the father. In 2012 the mother was charged with defamation of the father, although because of a procedural error she was not convicted on this charge. She was, however, convicted of willful frustration of the father's parental responsibility rights (Rechtspraak, 2012). In the meantime, the children had been exposed to three years of interviews, investigations and other forms of stress, but most importantly the relationship between the father and his children had been irreparably damaged (Zembla, 2009).

In Europe, each year approximately two in every 1000 people divorce; in the United States this number is slightly higher with 3.6 in every 1000 people (Eurostat, 2014; Centers for Disease Control and Prevention, 2014). Around half of the divorces in Europe involve minor children (Organisation for Economic Co-operation and Development, 2014), which for instance in the Netherlands amounts to approximately 33,000 children per year (Centraal Bureau voor de Statistiek, 2013, 2014a). Although in the majority of divorce cases spouses petition for divorce jointly, approximately 40\% of divorces are unilateral (Centraal Bureau voor de Statistiek, 2014b). Some of these cases are high-conflict cases (Dutch “vechtscheidingen”), with ex-spouses fighting about property division, maintenance and, above all, custody of and access to the children. Comparative research shows that during divorce procedures fights between the spouses that are related to the children sometimes take the shape of real “gender wars" (Rhoades \& Boyd, 2004). During some of these high-conflict divorces, allegations of sexual abuse of the children are made, which complicate the conflict even more. Typically in these cases, the mother accuses the father of the sexual abuse of one or more of their children. Sometimes persons other than the father (e.g., the new partner of the mother) are accused, and persons other than the mother (e.g., the father) accuse/ make accusations. Sometimes such allegations are even made long after the divorce is finalized, in the context of access disputes. Although extreme, the above case, in which one parent accused the other of sexual abuse of their children, is clearly not an isolated one. Some professionals have suggested that child sexual abuse (CSA) allegations during divorce procedures have actually increased since the 1980s (Myers, 1990; Thoennes \& Pearson, 1988).

Some authors have argued that divorce procedures are a natural moment for sexual abuse to be revealed. During marriage, the other parent may (either consciously or unconsciously) have turned a blind eye due to fear of, or loyalty towards, the abusing parent. The breakdown of the relationship might liberate the mother from the control and fear of the father, especially when it was an abusive relationship, and could make her feel safe enough to verbalize/express her knowledge or suspicion of the abuse. Moreover, during the process of divorce, the mother may feel less dependent on the father or be more receptive to signals of abuse (Myers, 1990). In addition, abused children might feel freer to disclose the truth after the abusing parent has left home. Conversely, sexual abuse might be more likely to occur post-divorce. For fathers, the emotional conditions following the divorce and being “abandoned” by the mother might instigate "acting out”, which could result in actual sexual abuse of one or more children (Corwin, Berliner, Goodman, Goodwin, \& White, 1987).

Although divorce and the period following it are phases in which sexual abuse is likely to emerge, some reports have argued that divorce can also elicit false allegations of sexual abuse. It has been suggested that policies on parental responsibility, child residence and contact arrangements might provide mothers with an opportunity to damage the reputation of the father by accusing him of sexual abuse in order to gain advantage for herself, such as obtaining single custody or withholding access to the children. For example, as from 2009 Dutch family law states that after a divorce both parents equally share in the care and upbringing of the children (Wet van 27 November 2008 totwijziging, 2009).

It is common knowledge that CSA can have serious consequences for victims, both psychological and in terms of various other life outcomes. CSA is associated with increased risk for depression, drug and alcohol abuse, and physical problems such as obesity in adulthood (Trickett, Noll, \& Putnam, 2011). CSA committed by a parent is potentially even more damaging because it occurs within the legally and socially protected privacy of the nuclear family (Molnar, Buka, \& Kessler, 2001). Parental divorce is also associated with negative outcomes in the children such as low education, weak family ties, low psychological wellbeing, and delinquent and aggressive behavior (Amato \& Cheadle, 2005; Valk, Spruijt, de Goede, Maas, \& Meeus, 2005). These outcomes are more likely to occur when conflicts are violent and abusive (Fosco, DeBoard, \& Grych, 2007; Holt, Buckley, 
\& Whelan, 2008). Children who experience both sexual abuse by a parent and parental divorce are at significant risk of these outcomes: Afifi, Boman, Fleisher, and Sareen (2009) found that when child abuse is accompanied by divorce or separation, poor mental health outcomes for the child are significantly more likely than when separation/divorce or child abuse occur independently. Specifically, there are increased risks of lifetime posttraumatic stress disorder, conduct disorder, and suicide attempts.

All this implies that high demands are made upon civil or specialized family judges who are hearing divorce cases in which allegations of CSA are made. Judges are tasked with deciding on matters such as custody and access, on which extremely serious allegations are superimposed. This is made all the more difficult because, given the antagonistic setting between the parents, the risk of false allegations cannot be ruled out. This means that judges are faced with a dilemma. Not taking the sexual abuse allegation seriously might result in failing to intervene in a harmful situation for the child (ren), and allow the abuse to continue (risk of false-negative). Taking every allegation seriously, even if it is unfounded, means exposing the child (ren) and the accused parent to a painful and often long-running investigation, which could damage both the parent-child relationship and the psychological well-being of both child and parent (risk of false-positive).

Therefore, sexual abuse allegations during divorce proceedings put extremely high demands on judges. Children may or may not be at risk of being damaged by sexual abuse, while the judicial response itself may be harmful. Some authors have suggested that increasing numbers of divorce proceedings are accompanied by allegations of sexual abuse. However, much is unknown about these processes, such as the prevalence of CSA during divorce procedures; the proportion of unfounded allegations, and of these, the proportion that have been purposely fabricated; whether judges have specific rules or guidelines to act upon; how judges handling divorce cases respond to such allegations; and finally, the consequences for children and the accused parent of false negatives (not intervening when abuse occurs) and false positives (intervening when abuse does not occur). That so little is known about these issues may be partially attributed to the fact that any existing literature is generally scattered over different disciplines such as family law, criminology, victimology, child studies, and psychology.

In this paper we aim to address this lack of information by reviewing the available literature on this topic. The paper adds to the existing literature by combining empirical findings from a number of disciplines, to provide an overview of what is known about the prevalence of allegations of CSA, the decisions judges make, and the long-term outcomes for the parents and children involved.

\section{Research Questions}

This study addresses four research questions:

- What is the prevalence of CSA allegations in divorce procedures?

- How do family court judges respond to CSA allegations in divorce procedures?

- What is known about the ratio of founded versus unfounded allegations of CSA under these circumstances?

- What are the possible consequences of false positives and false negatives in legal decision making for the children and parents involved?

\section{Method}

\subsection{Selection of Articles}

We adopted three search methods to collect all relevant literature. First, a systematic search was conducted on the Web of Knowledge, Web of Science, Hein Online, and Psych INFO databases, using two groups of keywords in combination with each other. The first group of keywords refers to the concept of divorce, although it is not limited to divorce as we also included other indicators of marriage breakdown or separation (custody, parental responsibility, visitation, divorce, marital breakdown, parental separation, and litigation). The second group of keywords refers to the concept of child sexual abuse (child sexual abuse, child abuse, allegations (of) sexual abuse, and childhood sexual abuse). The search was not limited to specific years since our objective was to have a complete overview of all the literature and, as we expected, the electronic search yielded a small number of relevant publications. For this reason, a snowball method was used as a second method for collecting literature; we searched all relevant retrieved publications for other publications that met our criteria.

As a third method we consulted experts (from Belgium, Norway, Italy, Sweden, Scotland and Finland) on family law, criminology and child custody cases for literature that was forthcoming or that had been published 
in a language other than English. The experts were contacted via email either because they were professional acquaintances, or known through professional acquaintances of one of the authors. By consulting experts in various countries, we hoped to extend our search to non-English articles. We additionally contacted specialists in the field of child sexual abuse who recommended various studies on the definitions and consequences of this kind of abuse.

\subsection{Definitions}

Child Sexual Abuse: Studies on CSA employ varying definitions of CSA. Differences are related to cut-off age, which determines at what age the victim is no longer a child and therefore the abuse cannot be qualified as CSA. Some of the studies opt for 18 years, while others choose the age of consent (the age at which a person is considered legally competent to consent to sexual acts) as determined by law. However, age of consent is considered for normal sexual acts, but not incest. Therefore, in light of this review, the cut-off age that is used for this study is 18 years old.

Other important factors in which the definition of CSA diverges are the type of perpetrator of the abuse and what type of sexual acts are qualified as CSA (Stoltenborgh, van IJzendoorn, Euser, \& Bakermans-Kranenburg, 2011). For our review we adopt the definition of CSA as used by Alink et al. (2011) in their Dutch Prevalence Study on Child and Youth Abuse. Within this definition, the perpetrator of the abuse must be a parent or a person on whom the minor relies, such as a guardian or schoolteacher. This distinction is important in light of the topic of this literature review, where the abuse has taken place within the nuclear family and is perpetrated by, in general, the parent but who may also be a stepparent or partner of a parent. The definition is broad and includes "hands-on" abuse as well as "hands-off" abuse, such as voyeurism and indecent exposure.

Allegation: In this article, the voicing of a suspicion of CSA is referred to as an "allegation"; consequently the person who alleges the CSA is the "alleging parent", and the other parent is referred to as the "alleged abuser". We decided to use the term "allegation" instead of "accusation" because of the wider range of meaning. An accusation of CSA entails a strong conviction that the abuse actually took place, while an allegation can also be a suspicion.

Divorce: This literature review is focused on allegations of CSA during a divorce procedure, and therefore will not include literature that is solely related to custody and visitation disputes. These allegations can coincide with the filing of divorce by either one or both of the parents, but can also occur long after the divorce has been finalized. Consequently, when we speak of CSA allegations during divorce, we include custody and visitation disputes during the divorce procedure.

\section{Results}

The electronic search yielded 67 articles. Snowballing the articles generated a further six relevant publications. Our consultation with specialists produced 8 further relevant publications. All in all, we found 81 publications that met our search criteria. Upon inspection, only 20 were relevant for our purposes in the sense that they provided data relevant to our research question. It should be noted that among these relevant publications there were reviews that reported on earlier research also implemented in this study. A total of 14 publications were published in the last 10 years; 4 studies were published more than 20 years ago. Table 1 gives an overview of all relevant publications.

\subsection{Prevalence}

Very few studies gave information on the prevalence rate of CSA allegations during divorce procedures. The literature search yielded two relevant empirical studies, both from the United States and both over twenty years old. Thoennes and Pearson (1988) estimated that CSA allegations occurred in between 2 and 15 per 1000 divorce cases in the United States. Thoennes and Tjaden (1990) conducted an empirical study in twelve courts in the United States and reviewed 169 custody or visitation dispute cases. They concluded that sexual abuse allegations are made in no more than an average of $2 \%$ of contested custody and access cases in the context of parental separation, that is in divorce procedures as well as custody and access disputes after separation. All in all, from these two American studies we conclude that CSA is a rare event in divorce proceedings: CSA allegations are made in no more than roughly $2 \%$ of divorce cases. 
Table 1. Relevant publications.

\begin{tabular}{|c|c|c|c|c|}
\hline Author (s) & Year & Title & Country & Sample \\
\hline Afifi et al. & 2009 & $\begin{array}{l}\text { The relationship between child abuse, parental } \\
\text { divorce, and lifetime mental disorders and } \\
\text { suicidality in a nationally representative adult } \\
\text { sample }\end{array}$ & Canada & 5877 adults \\
\hline Bala et al. & 2007 & $\begin{array}{l}\text { Sexual Abuse Allegations and Parental } \\
\text { Separation: Smokescreen or Fire? }\end{array}$ & $\begin{array}{c}\text { United } \\
\text { States/Canada }\end{array}$ & review of various studies \\
\hline Bala \& Schuman & 1999 & $\begin{array}{l}\text { Allegations of Sexual Abuse when Parents } \\
\text { have Separated }\end{array}$ & Canada & review of various studies \\
\hline Blodgett & 1987 & $\begin{array}{l}\text { Spouses use allegations to up the ante in } \\
\text { divorce cases }\end{array}$ & United States & NA \\
\hline Blush \& Ross & 1987 & $\begin{array}{l}\text { Sexual Allegations in Divorce: the SAID } \\
\text { Syndrome }\end{array}$ & United States & $\begin{array}{l}\text { Number unknown } \\
\text { (investigations at a family service clinic) }\end{array}$ \\
\hline Bow et al. & 2002 & $\begin{array}{l}\text { Assessment of Sexual Abuse Allegations in } \\
\text { Child Custody Cases }\end{array}$ & United States & 84 psychologists \\
\hline Brown et al. & 2000 & $\begin{array}{l}\text { Revealing the Existance of Child Abuse in the } \\
\text { Context of Marital Breakdown and Custody } \\
\text { and Access Disputes }\end{array}$ & Australia & 200 families \\
\hline Cobley & 2006 & $\begin{array}{l}\text { The Quest for Truth: Substantiating } \\
\text { Allegations of Physical Abuse in Criminal } \\
\text { Prosecutions and Care Proceedings }\end{array}$ & United Kingdom & NA \\
\hline Faller & 1991 & $\begin{array}{l}\text { Possible Explanations for Child Sexual Abuse } \\
\text { Allegations in Divorce }\end{array}$ & United States & 136 cases of CSA allegations during divorce \\
\hline Green & 1986 & $\begin{array}{l}\text { True and False Allegations of Sexual Abuse in } \\
\text { Child Custody Disputes }\end{array}$ & United States & NA (2 case illustrations) \\
\hline McGraw \& Smith & 1992 & $\begin{array}{l}\text { Child Sexual Abuse Allegations amidst } \\
\text { Divorce and Custody Proceedings }\end{array}$ & United States & $\begin{array}{l}18 \text { cases of CSA allegations in divorce and } \\
\text { custody disputes }\end{array}$ \\
\hline Myers & 1990 & $\begin{array}{l}\text { Allegations of Child Sexual Abuse in Custody } \\
\text { and Visitation Litigation: Recommendations } \\
\text { for Improved Fact Finding and Child } \\
\text { Protection }\end{array}$ & United States & NA \\
\hline Peterson & 1995 & $\begin{array}{l}\text { Judicial Discretion is Insufficient: Minor's Due } \\
\text { Process Right to Participate with Counsel } \\
\text { when Divorce Custody Disputes Involve } \\
\text { Allegations of Child Sexual Abuse }\end{array}$ & United States & NA (review of state law) \\
\hline Schafran & 1997 & $\begin{array}{l}\text { Adjudicating Allegations of Child Sexual } \\
\text { Abuse when Custody is in Dispute }\end{array}$ & United States & NA \\
\hline Sirles \& Lofberg & 1990 & $\begin{array}{l}\text { Factors Associated with Divorce in } \\
\text { Intrafamily Child Sexual Abuse Cases }\end{array}$ & United States & 128 cases of intrafamilial sexual abuse \\
\hline $\begin{array}{l}\text { Thoennes \& } \\
\text { Pearson }\end{array}$ & 1988 & $\begin{array}{l}\text { Summary of Findings from the Sexual Abuse } \\
\text { Allegations Project }\end{array}$ & United States & $\begin{array}{l}25 \text { large domestic relations courts, } 300 \\
\text { questionnaires } \\
\text { from judges and AFCC, and in-depth } \\
\text { interviews at five sites }\end{array}$ \\
\hline $\begin{array}{l}\text { Thoennes \& } \\
\text { Tjaden }\end{array}$ & 1990 & $\begin{array}{l}\text { The Extent, Nature, and Validity of Sexual } \\
\text { Abuse Allegations in Custody Visitation } \\
\text { Disputes }\end{array}$ & United States & $\begin{array}{c}\text { surveys, interviews and } 169 \text { cases of CSA } \\
\text { allegations } \\
\text { within a custody/visitation dispute }\end{array}$ \\
\hline $\begin{array}{l}\text { Trocmé \& } \\
\text { Bala }\end{array}$ & 2005 & $\begin{array}{l}\text { False Allegations of Abuse and Neglect when } \\
\text { Parents Separate }\end{array}$ & Canada & $\begin{array}{c}7672 \text { child maltreatment investigations from } \\
51 \text { child welfare service areas }\end{array}$ \\
\hline $\begin{array}{l}\text { Wakefield \& } \\
\text { Underwager }\end{array}$ & 1991 & $\begin{array}{l}\text { Sexual Abuse Allegations in Divorce and } \\
\text { Custody Disputes }\end{array}$ & United States & NA \\
\hline Zarb & 1994 & $\begin{array}{l}\text { Allegations of sexual abuse in custody and } \\
\text { access disputes: What care is in the best } \\
\text { interest of the child }\end{array}$ & Canada & NA: Relevant legislation and recent case law \\
\hline
\end{tabular}




\subsection{Judicial Response}

Six studies described judges' responses to CSA allegations. The manner in which judges respond to such an allegation depends on the legal system of particular countries or jurisdictions. Four findings emerge from the studies on judicial response. First, in the studies conducted in the U.S., Canada and Australia described below, civil judges are reported to seek professional advice when confronted with an allegation of CSA during a divorce procedure. Generally judges inform Child Protective Services who then start an investigation, while mental health professionals are often also included in these types of cases, either through CPS or directly. Second, in many cases the judge temporarily suspends access or custody between accused parent and child, although the percentage is unclear. Third, legal systems differed regarding the process by which judges arrive at their decisions. In Canada, the police appear to be called in more often than in America and Australia. Additionally, in the Unites States, judges occasionally subject both parents to monitoring or supervised visitation. The last conclusion that can be drawn concerning judicial response is that almost every study discussed here highlights the problem of the involvement of multiple players, notably judges, CPS personnel, and mental health professionals, which causes delays and negatively impacts the case. We will now discuss these findings in more detail.

Professional help: An Australian study (Brown, Frederico, Hewitt, \& Sheehan, 2000) explored court records of approximately 200 families and shows how federal family courts in Australia deal with child abuse (not limited to sexual abuse) in the context of legal and de facto marital breakdown. In Australia, separate authorities provide Child Protective Services (CPS) and other child welfare services. When a family court is informed of-or discovers-child abuse, proceedings are generally suspended and the court refers the case to CPS for investigation until CPS comes with a formal response. The authors note that such cases take, on average, 17.5 months from allegation to resolution. The duration increases as the age of the child decreases and the parents' rights to repeatedly bring the case back to the court causes additional delays.

An earlier study from the United States (Thoennes \& Pearson, 1988) shows that when a CSA allegation is made in family court, the standard response is to report this to CPS, although it is at the family court officers' discretion as to whether or not an allegation is reported. Some courts do not align with the approach CPS takes in the investigation, and the study even reports:

(...) a reluctance on the part of CPS agencies to seriously investigate abuse charges in divorce/custody cases. Caseworkers may dismiss such cases as undoubtedly false or assume that the domestic relations court will protect the child. If the child is not living with the allegedly abusive parent, the case may not be perceived to involve imminent danger, thus resulting in a lower case priority. (p. 8)

Therefore, some courts choose to play a more active role by starting a more general family court-supervised evaluation of the family concurrent with the CPS investigation, even when it is believed that CPS is conducting its investigation adequately. The authors indicate that it is unclear how judges respond in cases where the court and CPS reach different conclusions. Bow, Quinnell, Zaroff, and Assemany (2002) conducted a survey among mental health professionals who assess sexual abuse allegations in child custody cases. They report that due to the complexity of the responses that these cases require, family court judges often seek help of mental health professionals in evaluating the veracity of the allegations.

Decisions surrounding custody or access: According to a Canadian/American review (Bala, Mitnick, Trocme, \& Houston, 2007), civil judges tend to err on the side of caution when an allegation of CSA is made. This usually entails suspending visitation between the child and the accused parent until a court-ordered investigation is finished (Zarb, 1994). Even though in American legislation there is no mention of CSA as a factor in making "best interest" decisions related to children when settling divorce, custody, or access issues, it appears from the review that "best interest" does play an important role. From their analysis of a number of case studies, the authors conclude that when a judge finds that an allegation made by a custodial parentis unfounded, the alleging parent will commonly continue to have custody (Bala et al., 2007). When the allegation is judged to be founded, the judge generally terminates visitation rights, though s/he in some cases might allow visitation if it is considered to be in the child's best interest (e.g., because the child feels emotionally attached to the accused parent). In Australia, it is reported that courts often order a change in access or custody, and limit the accused parent's access to the child (Brown et al., 2000).

Although the authors do not give percentages, Bala and Schuman (1999) report that generally Canadian judges temporarily suspend unsupervised access by the accused parent pending a full hearing. In a few reported 
cases, judges allowed unsupervised access to continue if they found the evidence for the abuse weak. Bow et al. (2002) conducted a survey among mental health professionals and found that in cases of CSA allegations, judges either order supervised contact or, when professionals report that they deem alleged sexual abuse likely, suspend contact between the alleged perpetrator and the child.

When CSA is deemed likely to have occurred or likely to occur, judges in the United States can grant temporary custody to the alleging parent during the pendency of a divorce proceeding (Myers, 1990). The transfer of cases that involve an allegation of sexual abuse from family court to juvenile court is reportedly recommended by judges in some cases because this court is better equipped to investigate and try such allegations. However, the study does not indicate how often civil judges make this decision (Myers, 1990). Myers notes that in the United States family judges may also subject both parents to temporary supervision or monitoring in cases where it has been established that CSA has occurred but the identity of the perpetrator is unknown. In this reasoning, both parents have neglected to protect their child from sexual abuse. According to Myers (1990): "( $u$ )nder this approach, neither parent is stigmatized as a child abuser. Although stigma accompanies a finding of failure to protect, such opprobrium [sec] is of lesser magnitude than the stigma attached to a finding of abuse" (p. 34). Although this type of judicial response is not applicable to the most common type of CSA allegation, in which the identity of the alleged abuser is known, it is possible that a parent expresses her concern for abuse without directly accusing the father.

Differences in legal systems: A Canadian study (Bala et al., 2007) shows that in $46 \%$ of the cases that involve an ongoing custody or access dispute judges, the police is involved. Criminal charges were made in only $3 \%$ of the cases. The study uses the unpublished data of the Canadian Incidence Study of 2003, described in Trocmé, Tourigny, MacLaurin, and Fallon (2003). From the study it is unclear who involves the police. This could be the judge, a family member or any other involved person.

Civil judges in Canada who resolve disputes reportedly base their judicial assessment on the best interest of the child, although only in one province (Newfoundland) the law refers to abuse allegations in custody and access disputes. It specifies that "the court shall consider the person's history of 'violence' towards a spouse or any child when making a determination about whether that person shall have custody or access to a child" (Bala \& Schuman, 1999: p. 34). This is the only study that reports specific legislation for custody or access cases with CSA.

Many players: Thoennes and Pearson (1988) noted that CSA allegations may set off a "cascade" of actors, such as CPS workers, police, physicians, court representatives, and custody evaluators. These actors sometimes consecutively or concurrently deal with the same case, which causes duplicated efforts and delays. Bala et al. (2007) claim that all the involved agencies and professionals in sexual abuse cases during separation in fact further complicate the resolution of these cases because of their overlapping duties and at times contrasting interests. Different institutions could be operating in different courts at the same time. In an earlier Canadian review of studies on allegations of CSA surrounding parental separation (including divorce, custody, and access disputes), Bala and Schuman (1999) note how in such cases a criminal prosecution, a parental custody case and a child protection case may simultaneously take place. However, criminal and CPS investigations most likely take place only in cases where the evidence is clear. When it is uncertain if the abuse has occurred, the case will most likely be resolved in a family law proceeding.

Thoennes and Pearson (1988) recognize other complications in these types of cases. They mention that if more than one state or county is involved in the same case, for example when the divorce procedure takes place in a different state than where the marriage was contracted, the complexity further increases because of differences in policies and procedures. This may even be so if several courts within the same county are involved.

Much of the reviewed studies report on how judges should respond (recommendations), and simultaneously critique the status quo. However, it is unclear from the available studies, what options judges actually have. Strikingly absent from the literature is an overview of the kinds of decisions that judges tend to make concerning access and custody.

\subsection{Founded vs. Unfounded}

From the available empirical studies it may be inferred, albeit carefully because of the small number of studies, that one out of seven to eight cases of CSA during divorce appear to be unfounded. Studies that give information on outcomes may report that cases are founded (where it turns out that the children most likely were sexually 
abused), unfounded (where the opposite emerges) or it remains unclear whether the children were sexually abused or not. We will report on percentages that were reported to be unfounded, either because they were unsubstantiated or because they were proven to be deliberately falsely constructed.

Thoennes and Pearson (1988) reported that family court personnel had indicated that deliberately fabricated allegations are extremely rare, however the authors did not quantify this. In reviewing court records of around 200 families in custody and access disputes in Australia, Brown et al. (2000) found that around 9\% of the allegations had been proven to be false. In evaluating a small sample of 11 children in cases of suspected child sexual abuse in custody disputes, Green (1986) concluded that four out of the eleven cases had been fabricated. Bala et al. (2007) reviewed literature and presented national data from Canada. The data from the Canadian Incidence Study of Reported Child Abuse and Neglect of 2003 used in this report shows that 18\% of CSA allegations in the context of parental separation (12 cases) had been judged to be consciously fabricated, and thus false; 36\% (25 cases) were unsubstantiated but made in good faith. Thoennes and Tjaden (1990) reported that in one third of the 129 contested custody-visitation disputes (so a broader category than divorce) throughout the United States for which a determination of the validity of the allegation was possible, the abuse allegation turned out to be unfounded. Trocme and Bala (2005) analyzed data from the 1998 Canadian Incidence Study, and found that $12 \%$ of the child abuse allegations, not only sexual, in cases involving custody or access disputes was consciously fabricated. Therefore, according to this study, the percentage of consciously fabricated child sexual abuse cases is less than $12 \%$.

The Canadian Incidence Study of 2003 (Bala et al., 2007) showed that 34\% of the cases were suspected but not proven, and although in almost half (46\%) of the cases the police were involved, charges were laid in only $3 \%$ of the cases. This reflects the difficulty of acquiring evidence of the alleged abuse and the high number of unresolved cases. McGraw and Smith (1992) found that $11 \%$ of the 18 cases in their study lacked sufficient evidence and $28 \%$ were unsubstantiated suspicions. Based on a clinical sample of 136 cases of divorce with an allegation of CSA in Michigan (USA), Faller (1991) concludes that out of all cases, 19 (14\%) were proven false. McGraw and Smith (1992) analyzed 18 CSA cases that were investigated by the Boulder, Colorado (United States) Sexual Abuse Team concerning divorce and custody disputes, of which 3 (16.5\%) were found to be consciously fabricated. In their study of evaluations of mental health professionals, Bow et al. (2002) conclude that allegations of CSA were "supported" in around $30 \%$ of the cases that were referred.

All in all, we conclude that in the small percentage of cases where allegations of sexual abuse are made during divorce proceedings, between one in seven to eight of these eventually appear to be unfounded. However, this does not imply that the majority of cases are proven to be founded. Not surprisingly, quite a number of cases are not resolved and it remains unclear whether the allegation was founded or unfounded. Thoennes and Tjaden (1990) report that in $17 \%$ of the cases no conclusion could be reached and Faller (1991) reports that $9 \%$ of cases remain unclear.

\subsection{Consequences}

Very little information was found on (long-term) consequences of judges' decisions for children or parents involved in divorce disputes where CSA allegations were made. One study reported on children's well-being during the divorce process. In a study of approximately 200 Australian families where CSA allegations had been made during divorce or custody/visitation disputes, Brown et al. (2000) measured levels of distress of the children involved in these cases. Due to the long time of the investigation, the multiple hearings and a number of court ordered changes in custody and visitation, children were found to be suffering high levels of distress: "The longer the dispute took the greater was the child’s deterioration” (Brown et al., 2000: p. 856).

\section{Conclusion}

The literature review showed that amazingly little research is available on the issue of allegations of child sexual abuse (CSA) during divorce proceedings. In addition, the majority of the existing literature is from at least ten years ago. This indicates on the one hand that CSA in divorce proceedings is a longstanding issue. Few substantiations were found that this problem has grown, as hypothesized due to changes in family law that equalize fathers' and mothers' rights. The body of research is scattered between various fields; mostly psychology, family law, victimology and criminology, and most of the research we have found is conducted in just three countries (US, Australia and Canada). Quite a few studies used small samples or convenience samples. At the same time, 
many studies attested to the extremely difficult circumstances of such cases, for children, the accused parent, the accusing parent, as well as the judge.

Our first question concerned the prevalence of CSA allegations in divorce procedures. The existing body of relevant literature on prevalence of CSA during divorce procedure is so scarce (only two US studies) that we are not able to give a satisfactory answer to this question. The indication that can be derived from these two studies is that the prevalence lies around two percent of all divorce cases. Therefore, it appears to be a quantitatively small problem. No evidence on trends was found.

The second question was how judges hearing divorce cases respond to these allegations. Civil judges handling such allegations during divorce procedures are faced with a dilemma, needing to take into consideration both the risk of false negatives as well as false positives. The findings regarding the judicial responses can be roughly divided into four categories.

1) Professional help

Civil judges often seek professional advice, generally by informing Child Protective Services (CPS) who start their own investigation or by consulting mental health professionals either through CPS or independently.

2) Decisions surrounding custody and access

One of the most common interventions by judges appears to be a measure suspending or limiting contact for the duration of the investigation of the alleged abuse by the family court, CPS or criminal justice system.

3) Differences in legal systems

In Canada, it appears that the police are notified more often than in Australia and the United States. In the United States monitoring or supervised visitation can be extended to both parents, while it is unclear whether this is an option for Australian and Canadian judges as well.

4) Many players

The literature on judicial response shows that the involvement of many players in these cases aggravates matters, and decreases children's wellbeing.

Very little of the findings pertain to family law procedures per se. It does appear that judges seem to struggle with the problem and do not have specific procedures to follow.

Next, based on the empirical evidence, it can be carefully assumed that one out of seven to eight cases of CSA allegations during divorce is unfounded. It is important to note here that an allegation can also be unfounded while not consciously fabricated and overall sizable percentages of cases remained unsolved. However, some studies were small or employed convenience samples, or addressed a broader category than divorce procedures.

The final research question posed in this review concerned consequences of the false positives and false negatives in legal decision making for the children and parents involved. Although the negative effects of CSA and divorce on children and their parental relations appear self-evident, no studies gave conclusive evidence on this. Only one study linked the duration of the investigation, the multiple hearings, and changes in custody and visitation to higher levels of distress in children.

To conclude, the allegations of CSA during divorce proceedings are relatively uncommon. A small proportion of these is unfounded. Judges appear to frequently enlist the assistance of other institutions such as the Child Protection Services to help them judge to what extent an allegation is likely to be true. However, while a small proportion of allegations turn out to be unfounded, a substantial proportion also remains undecided. This underscores the extremely difficult and uncertain circumstances in which family law judges need to operate; with little evidence, little to no explicit guidelines, where external specialist advice also lengthens the case and the children's distress, and vast consequences for wrong decisions in either direction. However, even with these consequences in mind, the judge needs to make formal decisions for the child and family. The research that has been conducted on this topic is surprisingly scarce, and mostly dated. It gives few (if any) empirical bases for answers to our questions and as such suggests that further research is needed. Such research should focus on the long term in order to expose what happens after the divorce is finalized and when conclusions have been drawn regarding the allegation of CSA. By reviewing and researching multiple cases and their aftermath, it will be possible to determine the effects on the children of the uncertainty that the judge faced, the approach s/he chose and the outcome, relative to, for instance, the length of the legal process. In this way, possible recommendations could be made to improve judges' decision-making and the outcomes for the children.

\section{Recommendations for Research and Implications for Policy and Practice}

Although allegations of CSA during divorce are rare events, the problem is considered to be so serious that 
much of the research that we found poses recommendations on how the justice system could improve. In this discussion we highlight the most important of these recommendations. Some of the recommendations are directed towards the court in general or the judges in specific. Brown et al. (2000) recommend to create a new specialized interventionist system for the United States, tightly led and managed by the court, that are child focused with short timelines and new mechanisms for communication. The goal is to only have three hearings with 6 weeks between each hearing, and representation for the child. Along these lines, Thoennes and Pearson (1988) recommend better coordination between the various actors in order to reduce delays, duplicated efforts, contradictory orders, and general trauma inflicted on the child, while Brown et al. (2000) suggest to unify CPS, children's courts, and family courts through improved coordination mechanisms. Bala et al. (2007) warn that in some cases it might be wise for a judge to assess the methodology of experts who have conflicting opinions.

The majority of the recommendations are focused on the mental health professionals who are evaluating the veracity of the allegations. Faller (1991) describes four classes of CSA cases in divorce, and clinical implications are discussed. One of the implications is that mental health professionals should keep an open mind when assessing such cases and should appreciate the wide range of circumstances and dynamics surrounding the cases. The author does some further detailed practical recommendations for mental health professionals. Bala et al. (2007) note that in the United States, professional guidelines exist that are used in child custody cases, while no such guidelines exist for evaluating CSA in general or CSA in the context of custody disputes. Their research shows that only one third of the respondents (the mental health professionals) use some form of protocol, model or guideline. Most respondents indicated that they had constructed their own protocol. One of the recommendations in the article to ensure the safety of the child is to provide therapy by a skilled, neutral professional who can provide support for the child after the stresses of litigation and monitor for possible abuse. Additionally, they assert that there is also a need for better education and training of professionals and for more research in order to better understand the dynamics and characteristics of these cases, and to allow professionals to better distinguish between founded and unfounded allegations. Bow et al. (2002) feel there is an apparent need for comprehensive guidelines given that most mental health professionals indicated that they had constructed their own protocol. They suggest a model consisting of ten bullet points, including interviews with the alleged victim, psychological testing of the alleged parent, assessment of the allegation, and the role of the evaluator. The objective of this model is to provide comprehensive, legally defensible evaluations that look after the best interests of all involved parties.

There were a few general recommendations not specifically directed towards the court or mental health professionals. Thoennes and Pearson (1988) conclude with some recommendations for the evaluation report including taking more family dynamics into account. Bala et al. (2007) pose detailed recommendations for the child, the accusing and the accused parent, and whoever represents these parties. They conclude by saying that some of the recommendations made might be too expensive, and many parents cannot afford the appropriate representation or professionals. Therefore, the authors suggest that the community should provide more support for these services and cases.

Lastly, a non-empirical Dutch article (Van Leuven, 2002), written by a judge and mediator, gives explicit recommendations for judges on how to respond to CSA allegations in divorce cases. The author bases these recommendations on his personal experiences and are extensions of the Parental Alienation Syndrome (PAS) as introduced by Gardner (1985). Van Leuven highlights the importance of recognizing that even though a CSA allegation during a divorce could call for a response within a public law case, it will have an impact on the privacy of the family. Van Leuven recommends stimulating the interaction within the family after an allegation has been made (especially between the partners). According to Van Leuven, a forensic expert should evaluate the case, and when the allegation is most likely founded, a criminal case should be started. If the allegation is most likely made due to relationship and communication problems, it is very important that the child remains to have contact with both parents, in order to avoid the development of parental alienation. If this is not possible, the child should reside with the parent that is the most emotionally stable, which is most likely the accused parent. This could be seen as a paradoxical move, although according to Gardner this is the only way to prevent or cure PAS (Gardner, 1985).

All of these recommendations are useful to some extent, although empirical research is needed in order to assess their "success". Our research indicates that scarce research has been conducted on this topic and therefore there is a lack of systematic knowledge. However, we acknowledge that our review was limited in a number of ways. First, we were restricted by the language, and could only search in the electronic databases for English 
studies. We were partly able to solve this problem by consulting experts from non-English speaking countries. Second, relevant studies that have not been included in electronic databases were not found. Although this was a limitation to our research, the lack of availability of (especially older) studies is a problem that is faced by others as well.

\section{Fund}

This research is financed by the Netherlands Organisation for Scientific Research (NWO).

\section{References}

Afifi, T. O., Boman, J., Fleisher, W., \& Sareen, J. (2009). The Relationship between Child Abuse, Parental Divorce, and Lifetime Mental Disorders and Suicidality in a Nationally Representative Adult Sample. Child Abuse \& Neglect, 33, 139147. http://dx.doi.org/10.1016/j.chiabu.2008.12.009

Alink, L., IJzendoorn, R. V., Bakermans-Kranenburg, M., Pannebakker, F., Vogels, T., \& Euser, S. (2011). Kindermishandeling in Nederland anno 2010: De tweede Nationale Prevalentiestudie Mishandeling van kinderen en jeugdigen (NPM-2010): Casimir Leiden.

Amato, P. R., \& Cheadle, J. (2005). The Long Reach of Divorce: Divorce and Child Well-Being across Three Generations. Journal of Marriage and Family, 67, 191-206. http://dx.doi.org/10.1111/j.0022-2445.2005.00014.X

Bala, N. M. C., \& Schuman, J. (1999). Allegations of Sexual Abuse When Parents Have Separated. Canadian Family Law Quarterly, 17, 191-243.

Bala, N. M. C., Mitnick, M., Trocme, N., \& Houston, C. (2007). Sexual Abuse Allegations and Parental Separation: Smokescreen or Fire? Journal of Family Studies, 13, 26-56. http://dx.doi.org/10.5172/jfs.327.13.1.26

Bow, J. N., Quinnell, F. A., Zaroff, M., \& Assemany, A. (2002). Assessment of Sexual Abuse Allegations in Child Custody cases. Professional Psychology-Research and Practice, 33, 566-575. http://dx.doi.org/10.1037/0735-7028.33.6.566

Brown, T., Frederico, M., Hewitt, L., \& Sheehan, R. (2000). Revealing the Existence of Child Abuse in the Context Of marital Breakdown and Custody and Access Disputes. Child Abuse \& Neglect, 24, 849-859.

http://dx.doi.org/10.1016/S0145-2134(00)00140-X

Centers for Disease Control and Prevention (2014). Marriage and Divorce. http://www.cdc.gov/nchs/fastats/marriage-divorce.htm

Centraal Bureau voor de Statistiek (2013). Echtscheiding; leeftijdsverschil, kinderen, geboorteland, huwelijksduur. http://statline.cbs.nl/StatWeb/publication/?DM=SLNL\&\&PA=60060ned

Centraal Bureau voor de Statistiek (2014a). Huwelijksontbindingen; door echtscheiding en door overlijden. http://statline.cbs.nl/Statweb/publication/?VW=T\&DM=SLNL\&PA=37425ned\&D1=a\&D2=0,10,20,30,40,50,(l-1)-l\&HD $=150512-1546 \&$ HDR $=\mathrm{G} 1 \& \mathrm{STB}=\mathrm{T}$

Centraal Bureau voor de Statistiek (2014b). Echtscheidingsprocedures, 1993-2013. http://statline.cbs.nl/Statweb/publication/?DM=SLNL\&PA=37192\&D1=0-7\&D2=a\&HDR=G1\&STB=T\&VW=T

Corwin, D. L., Berliner, L., Goodman, G., Goodwin, J., \& White, S. (1987). Child Sexual Abuse and Custody Disputes No Easy Answers. Journal of Interpersonal Violence, 2, 91-105. http://dx.doi.org/10.1177/088626087002001006

Eurostat (2014). Crude Divorce Rate. http://epp.eurostat.ec.europa.eu/tgm/table.do?tab=table\&init=1\&language=en \&pcode=tps00013\&plugin=0

Faller, K. C. (1991). Possible Explanations for Child Sexual Abuse Allegations in Divorce. American Journal of Orthopsychiatry, 61, 86-91. http://dx.doi.org/10.1037/h0079227

Fosco, G. M., DeBoard, R. L., \& Grych, J. H. (2007). Making Sense of Family Violence: Implications of Children’s Appraisals of Interparental Aggression for Their Short- and Long-Term Functioning. European Psychologist, 12, 6-16. http://dx.doi.org/10.1027/1016-9040.12.1.6

Gardner, R. A. (1985). Recent Trends in Divorce and Custody Litigation. Paper Presented at the Academy Forum.

Green, A. H. (1986). True and False Allegations of Sexual Abuse in Child-Custody Disputes. Journal of the American Academy of Child and Adolescent Psychiatry, 25, 449-456. http://dx.doi.org/10.1016/S0002-7138(10)60001-5

Holt, S., Buckley, H., \& Whelan, S. (2008). The Impact of Exposure to Domestic Violence on Children and Young People: A Review of the Literature. Child Abuse \& Neglect, 32, 797-810. http://dx.doi.org/10.1016/j.chiabu.2008.02.004

McGraw, J. M., \& Smith, H. A. (1992). Child Sexual Abuse Allegations Amidst Divorce and Custody Proceedings. Journal of Child Sexual Abuse, 1, 49-62. http://dx.doi.org/10.1300/J070v01n01_04

Molnar, B. E., Buka, S. L., \& Kessler, R. C. (2001). Child Sexual Abuse and Subsequent Psychopathology: Results from the 
National Comorbidity Survey. American Journal of Public Health, 91, 753-760.

Myers, J. E. B. (1990). Allegations of Child Sexual Abuse in Custody and Visitation Litigation: Recommendations for Improved Fact Finding and Child Protection. Journal of Family Law, 28, 1-41.

Organisation for Economic Co-Operation and Development (2014). Family Dissolution and Children. http://www.oecd.org/els/soc/SF_3_2_Family_dissolution_and_children_Oct2014.pdf

Rechtspraak (2012). Geen straf voor beschuldigen ex-man in tv-programma Zembla. http://www.rechtspraak.nl/Organisatie/Rechtbanken/Zeeland-West-Brabant/Nieuws/Pages/Geen-straf-voor-beschuldigen-e x-man-in-tv-programma-Zembla.aspx

Rhoades, H., \& Boyd, S. B. (2004). Reforming Custody Laws: A Comparative Study. International Journal of Law, Policy and the Family, 18, 119-146. http://dx.doi.org/10.1093/lawfam/18.2.119

Stoltenborgh, M., van IJzendoorn, M. H., Euser, E. M., \& Bakermans-Kranenburg, M. J. (2011). A Global Perspective on Child Sexual Abuse: Meta-Analysis of Prevalence around the World. Child Maltreatment, 16, 79-101. http://dx.doi.org/10.1177/1077559511403920

Thoennes, N., \& Pearson, J. (1988). Summary of Findings from Sexual Abuse Allegations Project. In B. Nicholson (Ed.), Sexual Abuse Allegations in Custody and Visitation Cases (pp. 1-19). Washington DC: National Legal Resources Center for Child Advocacy and Protection.

Thoennes, N., \& Tjaden, P. G. (1990). The Extent, Nature, and Validity of Sexual Abuse Allegations in Custody Visitation Disputes. Child Abuse \& Neglect, 14, 151-163. http://dx.doi.org/10.1016/0145-2134(90)90026-P

Trickett, P. K., Noll, J. G., \& Putnam, F. W. (2011). The Impact of Sexual Abuse on Female Development: Lessons from a Multigenerational, Longitudinal Research Study. Development and Psychopathology, 23, 453-476. http://dx.doi.org/10.1017/S0954579411000174

Trocmé, N. M., Tourigny, M., MacLaurin, B., \& Fallon, B. (2003). Major Findings from the Canadian Incidence Study of Reported Child Abuse and Neglect. Child Abuse \& Neglect, 27, 1427-1439. http://dx.doi.org/10.1016/j.chiabu.2003.07.003

Trocmé, N., \& Bala, N. (2005). False Allegations of Abuse and Neglect When Parents Separate. Child Abuse \& Neglect, 29, 1333-1345. http://dx.doi.org/10.1016/j.chiabu.2004.06.016

Valk, I. V. D., Spruijt, E., de Goede, M., Maas, C., \& Meeus, W. (2005). Family Structure and Problem Behavior of Adolescents and Young Adults: A Growth-Curve Study. Journal of Youth and Adolescence, 34, 533-546. http://dx.doi.org/10.1007/s10964-005-8841-8

Van Leuven, C. A. R. M. (2002). De relationele aanpak voorop bij incestaangiften na scheiding. TREMA, 4, 169-172.

Wet van 27 november 2008 tot wijziging van Boek 1 van het Burgerlijk Wetboek en het Wetboek van Burgerlijke Rechtsvordering in verband met het bevorderen van voortgezet ouderschap na scheiding en het afschaffen van de mogelijkheid tot het omzetten van een huwelijk in een geregistreerd partnerschap. (2009). Stb. 500. Inwerkingtreding op 1 maart 2009, Stb. 2009, 56.

Zarb, L. H. (1994). Allegations of Childhood Sexual Abuse in Custody and Access Disputes: What Care Is in the Best Interests of the Child? Canadian Journal of Family Law, 12, 91-114.

Zembla (2009). Verdachte vaders. http://zembla.vara.nl/seizoenen/2009/afleveringen/24-05-2009 